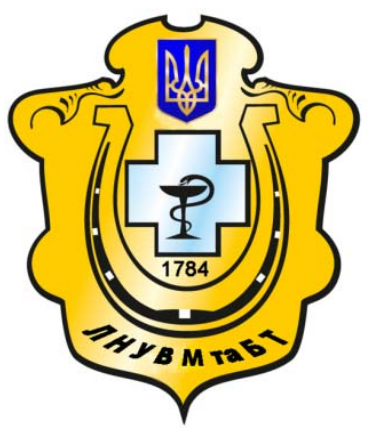

Науковий вісник Львівського національного університету ветеринарної медицини та біотехнологій імені С.3. Гжицького

Scientific Messenger of Lviv National University of Veterinary Medicine and Biotechnologies named after S.Z. Gzhytskyj

doi:10.15421/nvlvet7117

ISSN 2413-5550 print

ISSN 2518-1327 online

$\underline{\text { http://nvlvet.com.ua/ }}$

УДК 615.241.2:636.4

\title{
Фармакологічна дія препарату «Екосорб 25» та вплив на рівень напруженості імунітету свиней, що знаходяться на відгодівлі
}

\author{
Рибачук Ж.В. \\ zhrybachuk@ukr.net

\begin{abstract}
Житомирський начіональний агроекологічний університет, Старий бульвар, 7, м. Житомир, 10002, Украӥна
\end{abstract}

В статті приведені дані щодо доцільності використання препарату із адсорбуючими властивостями «Екосорб 25» для свиней, що знаходяться на відгодівлі. Проведеними дослідженнями доведено, щзо введення до складу рачіону вказаного адсорбенту із розрахунку 5 кг/1 тонну дерті зумовлює збільшення в сироватці крові вмісту імуноглобулінів. Встановлено, щзо у сироватиі крові свиней до застосування адсорбенту вміст імуноглобулінів був у широкому діапазоні $і$ середній показник

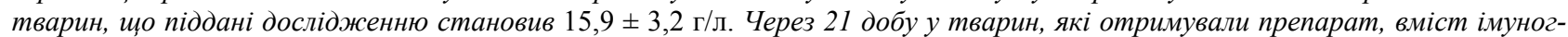
лобулінів був у фізіологічних межах і на 18,7\% більще в порівнянні із тваринами контрольної групи, які не отримували препарат із кормом.

Отримані результати засвідчують адсорбиійну здатність препарату «Екосорб-25» щзодо токсинів широкого спектру в просвіті шлунково-кишкового тракту свиней, щь знаходились на відгодівлі та дозволяють рекомендувати його для використання у складі раціону для профілактики та лікування інтоксикацій тварин.

Ключові слова: адсорбент, Екосорб 25, свині на відгодівлі, вміст імуноглобулінів, екзоінтоксикація, сироватка крові, ендоінтоксикація, мікотоксикози.

\section{Фармакологическое действие препарата «экосорб 25» и влияние на уровень напряженности имунитета свиней на откорме}

\author{
Ж.В. Рыбачук \\ zhrybachuk@ukr.net \\ Житомирский национальный агроэкологический университет, \\ Старый бульвар, 7, г. Житомир, 10002, Украина
}

\begin{abstract}
В статье приведены данные цеелесообразности использования препарата из адсорбционными свойствами «Экосорб-25» для свиней, что на откорме. Проведёнными исследованиями доведено, что введение в состав рациона указанного адсорбента из расчёта 5 кг/1 m корма обуславливает увеличение в сыворотке крови уровня иммуноглобулинов. Установлено, что в сыворотке крови свиней до примененния адсорбента уровень иммуноглобулинов был в широком диапазоне и средний показатель группы, что поддано исследованию, был 15,9 \pm 3,2 г/л. Через 21 сутки у животных, которые получали препарат, содержание иммуноглобулинов было в физиологичных пределах и на 18,7\% больше в сравнении с животными контрольной группы, которые не получали препарат с кормом. Через 2 месяиа после начала скармливания «Экосорба-25» свиньям контрольной группы, которые находились на откорме, содержимое иммуноглобулинов уменьшилось в сравнении с результатами предыдущего исследования (21 сутки) на 12\% до 14,0 \pm 0,76 г/л. В сыворотке крови опытной группь регистрировали достоверную $(P \geq 0,99)$ разнииу содержания иммуноглобулинов $(17,4 \pm 0,25$ г/л) в сравнении с животными контрольной $(14,0 \pm$ 0,76 г/л). Тоесть, на организм свиней контрольной группы, которые получали аналогические корма кроме адсорбента, 6 сравнинии из животными опытной, действовал имунодепресант.
\end{abstract}

Citation:

Rybachuk, Zh. (2016). The pharmacological action of the drug «Ekosorb 25» and the impact on tension immunity pigs are fattening. Scientific Messenger LNUVMBT named after S.Z. Gzhytskyj, 18, 3(71), 75-78. 
Полученные результаты удостоверяют адсорбционную способность препарата «Экосорб-25» относительно токсинов широкого спектра действия в желудочно-кишечном тракте свиней, что были на откорме и позволяют рекомендовать препарат для использования в составе рациона для профилактики и лечения интоксикаций животных.

Ключевые слова: адсорбент, Екосорб 25 свиньи на откорме, содержание иммуноглобулинов, екзоинтоксикация, сыворотка крови, эндочнтоксикации, микотоксикозы.

\title{
The pharmacological action of the drug «Ekosorb 25» and the impact on tension immunity pigs are fattening
}

\author{
Zh. Rybachuk \\ zhrybachuk@ukr.net
}

In the articles resulted the uses of preparation given inrelation to expediency are with adsorbent properties of «Ecosorb 25» for pigs that are on fattening. Undertakenstudies it is well-proven that introduction in the complementof ration of the indicated adsorbent from a calculation $5 \mathrm{~kg} / 1$ the ton of forage is predetermined by an increase in the serum of blood of content of immunoproteins. Content ofimmunoproteins is in the serum of blood of pigs, that it isexposed to research to application of adsorbent was differentand was in a wide range, a mean value was $15.9 \pm 3.2 \mathrm{gs} / \mathrm{l}$ immune status of investigational population is different Accordingly. Consider that such wide range of data testifiesto different activity of functioning of the immune system andconditioned by the different antigen loading each ofinvestigational animals. In a 21 twenty-four hours, after thebeginning of application of adsorbent of «Ecosorb 25» content of immunoproteins in the serum of blood of pigs of anexperience group is considerably less in comparing to theanimals that in composition a ration got «Ecosorb 25». Forthese pigs (control group) content of immunoproteins was at the level of a $16.6 \pm 1.27 \mathrm{~g} / \mathrm{l}$, but substantially differed for every animal, that testifiedtheir immune status to different. For the pigs of an experiencegroup a difference is between the least and maximal index ofcontent of immunoproteins presented $17.8 \%$ that specified onalmost identical reactivity of the immune system (reduction ofreceipt of antigens, maybe and mycotoxins from agastrointestinal tract). Got the given is conditioned by thedisplay of adsorbent action of preparation that is entered to the ration of pigs of an experience group. Positive influence of "Ecosorb 25» on functioning of the immune system atintroduction to the ration of pigs that are on fattening, theresults of research of serum of blood testify through 2 missesafter the beginning of application. Reduction to content of immunoproteins is registered in theserum of blood of pigs of control group on 15.7\% comparing to the previous index (21twentyfour hours) and $19.5 \%$ animals of an experience group. For certain $(P \geq 0,99)$ contentof immunoproteins increased in the serum of blood of pigs ofan experience group $17 \pm 0.25 \mathrm{gs} / \mathrm{of}$ to $14.0 \pm 0.76 \mathrm{~g} / \mathrm{l}$ that maybe it contingently the receipt of substances with animmunodepressive action (including and micotoxins) in the organism of animals of control group. Id est, at feeding to the pigs of preparation of «Ecosorb 25» with adsorbent properties during 2th months, stipulated reduction of receiptof toxins in blood, and accordingly and reduction offunctional activity immune. It provides rapid reactivity of the immune system andsynthesis of sufficient amount of antibodies at the hit ofmicroorganisms to the organism of pigs, that in compositiona ration got an adsorbent. As for the animals of control group registered reduction to content of immunoproteins in theserum of blood, it testifies to weakening of functional activityof the immune system. The difference of content ofimmunoproteins in the serum of blood of pigs testifies to the increase of providing of better immunological defence in the organism of animals of anexperience group and reduction of him in a control group.

Key words: adsorbent, Екосорб 25, pigs on fattening, content of immunoproteins, serum of blood, intoxication.

\section{Ветуп}

На ринку ветеринарних препаратів наявні значна кількість адсорбентів, які використовуються для профілактики чи усунення інтоксикацій організму різної етіології.

Синтезувати ідеальний адсорбент, що відповідав би усім вимогам (швидка дія, прояв фармакологічної дії не залежно від $\mathrm{pH}$ середовища, взаємодія із токсинами різних хімічних груп) не можливо, тому виробники синтезують препарати, що мають вибіркову дію. Так найширше представлений спектр ветеринарних адсорбуючих препаратів щодо мікотоксинів. Зокрема препарат Токсфін, Септокс, гіпохлорид натрію (ГХН-2), Мікофікс Плюс, Кормо-токс та інші (Kocjumbas, 2007).

Деякі ветеринарні препарати цієї групи мають, окрім адсорбуючої, інші фармакологічні дії. Так, за даними А. А. Грекової та А. Н. Мальцева застосування препаратів Гумівал і Полісорб ВП призводило до прояву антиоксидантного ефекту. А комплексний адсорбент Елітокс до складу якого включено ферменти (оксидази, лактонази і ін., які руйнують та дезактивують мікотоксини, утворюючи нетоксичні і екологічно безпечні метаболіти), органічний біополімерний адсорбент (зв'язує як полярні так і не полярні мікотоксини та має виражені антибактеріальні і протигрибкові властивості), неорганічний сорбент (який створює «ефект плівки») та рослинні екстракти і вітаміни (стимулюють роботу шлунково-кишкового тракту, діють гепатопротекторно, антистресово та імуностимулююче) (Kocjumbas, 2007).

Кількість лікарських засобів цієї групи постійно збільшується, оскільки при вирощуванні молодняку, а особливо відгодівельного поголів'я, тваринники реєструють зменшення продуктивності через екзоінтоксикації, які здебільшого обумовлені мікотоксикозами, до яких найчутливіші тварини 3 високою енергією росту (період відгодівлі, дорощування), лактуючі i глибокопоросні свиноматки. Провідні зарубіжні та вітчизняні науковці припускають, що лабораторні дослідження не завжди можуть виявити мікотоксини в кормах. Негативний результат досліджень аж ніяк не свідчить про відсутність токсинів (Kuznecov and Kuznecova, 2001; Burjak, 2007).

Відомо, що імуноглобуліни - здійснюють специфічний гуморальний захист шляхом розпізнання i зв'язування антигенів та гаптенів, мають важливий опсонізуючий ефект і виступають основним актива- 
тором системи комплементу. Завдяки імуноглобулінам реалізується основний етап захисту організму від мікроорганізмів, чужорідних білків, гаптенів та аутоантигенів.

Тому враховуючи поширення мікотоксикозів у свинарстві та імунодепресивну дію мікотоксинів, ми поставили за мету вивчити вплив адсорбенту «Екосорб-25» на вміст імуноглобулінів в сироватці крові свиней, які знаходяться на відгодівлі. Для досягнення мети необхідно виконати завдання:

- вивчити вміст імуноглобулінів без використання адсорбенту;

- з'ясувати динаміку змін вмісту імуноглобулінів протягом періоду використання препарату.

\section{Матеріал та методи досліджень}

Для проведення досліду, за принципом аналогів, було сформовано контрольну та дослідну групи тварин, що знаходились на відгодівлі. У свиней обох груп здійснювали відбір крові до початку введення до раціону препарату «Екосорб-25» та через 21 та 60 діб. Тваринам дослідної групи згодовували препарат у складі дерті із розрахунку 5 кг/1 тонну. Вміст імуноглобулінів в сироватці крові свиней проводили за загально прийнятою методикою.

\section{Результати та їх обговорення}

В приватному фермерському господарстві при вирощуванні відгодівельного поголів'я свиней породи Ландрас, за повноцінного раціону, реєстрували низькі прирости. Не зважаючи на те, що при дослідженні концентрованих кормів вміст мікотоксинів не перевищував норми ми допускали наявність інтоксикації тварин господарства, не виключаючи при цьому вплив мікотоксинів. А оскільки останні мають імунодепресивну дію ми провели визначення вмісту імуноглобулінів в сироватці крові відгодівельного поголів'я свиней дослідних груп. Результати дослідження представлено на рис.1.

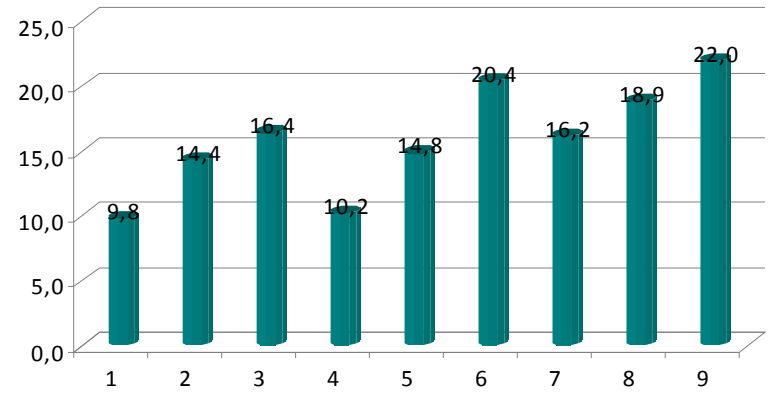

Рис. 1. Вміст імуноглобулінів у сироватці крові свиней до застосування препарату «Екосорб 25» (г/л)

Вміст імуноглобулінів в сироватці крові свиней, що піддано дослідженню до застосування адсорбенту був різний і знаходився в широкому діапазоні, що i видно із представленого рисунка. Зауважимо, що середнє значення було 15,9 $\pm 3,2$ г/л. Говорити про імунний статус поголів'я таких тварин дуже важко, оскільки отримані результати не дозволяють однозначно їх трактувати. Такий широкий діапазон даних свідчить про різну активність функціонування імунної системи і обумовлений, на нашу думку, різним антигенним навантаженням кожної із досліджених тварин.

Через 21 добу, після початку застосування адсорбенту, ми провели визначення вмісту імуноглобулінів в сироватці крові свиней дослідної та контрольної груп. Результати дослідження представлені на рис. 2.

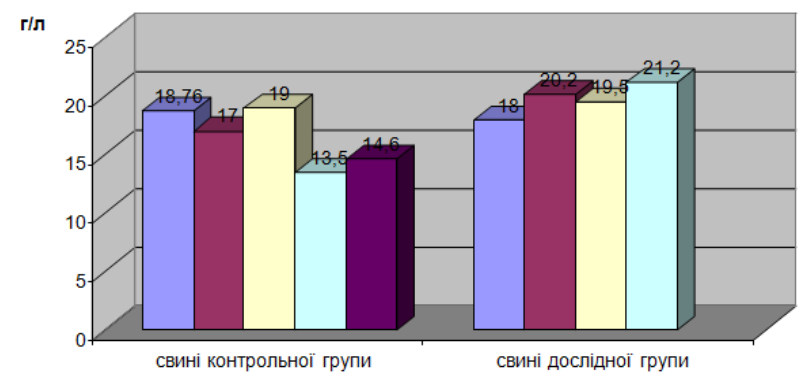

Рис. 2. Вміст імуноглобулінів в сироватці крові свиней через 21 добу застосування адсорбенту «Екосорб-25»

Отримані результати досліджень свідчать, що вміст імуноглобулінів в сироватці крові свиней дослідної групи значно менший в порівнянні із тваринами, які у складі раціону отримували Екосорб-25. У цих свиней (контрольна група) вміст імуноглобулінів суттєво відрізнявся в кожної тварини, що засвідчувало різний їхній імунний статус і в середньому був $16,6 \pm 1,27$ г/л.

У свиней дослідної групи різниця між найнижчим і максимальним показником вмісту імуноглобулінів становив $17,8 \%$, що вказує на майже однакову реактивність імунної системи. Адже майже однаковий рівень імуноглобулінів в сироватці крові тварин дослідної групи свідчить, на нашу думку, про зменшення надходження антигенів, можливо і мікотоксинів, в кров із шлунково-кишкового тракту. Отримані дані обумовлені проявом адсорбуючої дії препарату, який введено до раціону свиней дослідної групи.

Позитивний вплив на функціонування імунної системи при введенні до раціону свиней, що знаходяться на відгодівлі, Екосорбу-25 свідчать і результати дослідження сироватки крові через 2 міс після початку застосування адсорбенту. Так нами зареєстровано зменшення вмісту імуноглобулінів в сироватці крові свиней контрольної групи на $15,7 \%$ в порівнянні із попереднім показником (21 доба) та 19,5\% щодо тварин дослідної групи. Вважаємо, що отримані результати можуть бути обумовлені надходженням речовин iз імунодепресивною дією (в т.ч. і мікотоксини). Це підтверджується і достовірною різницею $(\mathrm{P} \geq 0,99)$ вмісту імуноглобулінів в сироватці крові свиней які отримували однакові корми (табл. 1).

Тобто, при згодовуванні свиням препарату «Екосорб-25» із адсорбуючими властивостями протягом 2-х місяців, обумовило зменшення надходження екзотоксинів у кров, а відповідно і зменшення функціональної активності імунної системи. 
Таблиияя 1

Динаміка змін вмісту імуноглобулінів в сироватці крові свиней при застосуванні адсорбенту «Екосорб 25»

\begin{tabular}{|c|c|c|c|c|c|}
\hline \multirow{3}{*}{ №п/п } & \multicolumn{5}{|c|}{ Вміст імуноглобулінів, г/л } \\
\hline & \multirow{2}{*}{$\begin{array}{c}\text { До згодовування } \\
\text { Екосорбу } 25, \\
n=9\end{array}$} & \multicolumn{2}{|c|}{ Через 21 добу: } & \multicolumn{2}{|c|}{ Через 2 місяці: } \\
\hline & & $\begin{array}{c}\text { Контрольна, } \\
\text { n }=5\end{array}$ & $\begin{array}{c}\text { Дослідна, } \\
\mathrm{n}=4\end{array}$ & $\begin{array}{c}\text { Контрольна, } \\
n=5\end{array}$ & $\begin{array}{c}\text { Дослідна, } \\
\text { n }=4\end{array}$ \\
\hline Середнє по групах & $15,9 \pm 3,2$ & $16,6 \pm 1,27$ & $19,7 \pm 0,71$ & $14,0 \pm 0,76^{*}$ & $17,4 \pm 0,25 * *$ \\
\hline Норма, г/л & \multicolumn{5}{|c|}{$17-20$} \\
\hline
\end{tabular}

Примітки: - в порівнянні із контролем: * - тенденція; $\quad$ ** $-\mathrm{P} \geq 0,99$

Це забезпечує швидку реактивність імунної системи та синтез достатньої кількості антитіл при потраплянні мікроорганізмів до організму свиней, що у складі раціону отримували адсорбент.

У тварин контрольної групи реєстрували зменшення вмісту імуноглобулінів в сироватці крові, що є свідченням ослаблення функціональної активності імунної системи, оскільки отримані результати менші нижньої фізіологічної межі на 17,65\%.

Отже, різниця вмісту імуноглобулінів у сироватці крові свиней свідчить про збільшення забезпечення високоспеціалізованого імунологічного захисту в організмі тварин дослідної групи та зменшення його в контрольній групі.

\section{Висновки}

1. Згодовування свиням, що знаходяться на відгодівлі, препарату «Екосорб-25» в дозі 5 кг/1 тонну концентрованих кормів призводить до зменшення інтоксикації організму і покращення функціонування їхньої імунної системи. Так через 21 добу після початку згодовування препарату реєстрували тенденцію щодо збільшення функціональної активності імунної системи до $19,7 \pm 0,71$ г/л в порівнянні із показниками тварин контрольної групи 16,6 \pm 1,27 г/л які не отри- мували адсорбент, а через 60 діб - 17,4 $\pm 0,25$ $(\mathrm{P} \geq 0,99)$ щодо тварин контрольної групи.

2. Адсорбент «Екосорб-25» у складі раціону свиней, що знаходяться на відгодівлі проявляє адсорбуючі властивості в просвіті шлунково-кишкового тракту, що обумовлює забезпечення високоспеціалізованого імунологічного захисту в організмі тварин дослідної групи та зменшення його в контрольній групі.

Перспективи подальших досліджень. Подальші дослідження будуть спрямовані на вивчення впливу адсорбенту «Екосорб-25» на зміни деяких гематологічних показників свиней, що знаходяться на відгодівлі.

\section{Бібліографічні посилання}

Kocjumbas, G. (2007). T-2 toksykoz porosjat i vplyv riznyh rozchynnykiv gipohlorydu natriju na perebig hvoroby (symptomatyka i patomorfologija. Suchasna veterynarna medycyna. 1, 28-30 (in Ukrainian).

Kuznecov, A. Kuznecova, I. (2001). Esli korma zarazheny mikotoksinami. Zhivotnovodstvo Rossii. 3, 5-6 (in Russian).

Burjak, V. (2007). Mikotoksikozy svynej i ih profilaktika. Zootehnija. 9, 17-18 (in Russian).

Стаття надійшла до редакиії 30.09.2016 